\title{
CHAPTER 14: VALORIZATION AND TREATMENT OF OILY WASTEWATERS FROM AGRO-INDUSTRIES USING LIPASES: AN OVERVIEW
}

\author{
Jéssica Mulinari ${ }^{1}$; Afonso Henrique da Silva Júnior ${ }^{2}$; Carlos Rafael Silva de Oliveira ${ }^{3}$; Francisco \\ Wilson Reichert Júnior ${ }^{4}$
}

\begin{abstract}
Oily wastewater from agro-industries can cause severe environmental and public health damages if unproperly treated. The conventional methods have several limitations for the treatment of oily wastewaters since the oil fraction can cause pipe clogging and biomass washout during the biological step. Based on this, the use of lipases can increase the oil removal efficiency of the treatments, minimizing operational problems, and improving the performance of the biological process. Lipases can also be used for the valorization of the oily wastewaters, transforming these waste streams into valuable compounds, such as biodiesel, lubricants, antioxidant agents, etc. The use of wastes for the production of value-added compounds follows the circular economy approach, minimizing the generation of residues and potential environmental liabilities. Thus, this study aims to give a general overview of the main topics related to the treatment and valorization of oily wastewaters using lipases. The main characteristics of oily wastewaters from agro-industries are addressed, as well as the most used conventional techniques for their treatment. Some relevant information about the enzyme lipase is also discussed to give the reader a background about how these enzymes can be applied for the treatment and transformation of oily wastes.
\end{abstract}

Keywords: Oily wastewater, Liquid effluent, Enzyme, Waste, Reuse.

\section{Introduction}

From agricultural production to consumption, a great amount of food is wasted. When uncorrected managed, these wastes can cause severe environmental and public health damages. With the growing population, food production will need to be intensified and, consequently, the amount of food waste will also increase. Therefore, it is necessary to develop new technological solutions to reduce food waste by avoiding its production, reusing, recycling or treating it in a more sustainable way.

Among food wastes, oily wastewaters can be a very dangerous environmental liability when unproperly treated or irresponsibly disposed of. The presence of oil in the wastewater can increase the treatment cost due to the need for more chemicals or operational problems such as pipe clogging, as well as decrease the treatment efficiency by inhibiting the growth and some

\footnotetext{
${ }^{1}$ Environmental and Sanitary Engineer (Federal University of Fronteira Sul - UFFS), Master in Chemical Engineering (Federal University of Santa Catarina - UFSC), PhD student in Chemical Engineering (UFSC), jessicamulinari15@gmail.com

${ }^{2}$ Agro-industrial Engineer (Federal University of Rio Grande - FURG), Master student in Chemical Engineering (UFSC), afonso.ufsc@gmail.com

${ }^{3}$ Textile Engineer (State University of Maringá - UEM), Master in Chemical Engineering (UFSC), PhD student in Chemical Engineering (UFSC), carlos.oliveira@ posgrad.ufsc.br

${ }^{4}$ Agronomist (UFFS), Master in Environmental Science and Technology (UFFS), PhD student in Plant Genetic Resources (UFSC), chicowrj@gmail.com
} 
metabolic pathways of essential microorganisms. On the other hand, the lipid-rich wastewaters from food industries have great potential to be used in the production of several value-added products. The valorization of wastes follows the circular economy approach being adopted in several industries, according to which wastes can be transformed from possible environmental contaminants into potential revenue streams. However, conventional transformation techniques generally require chemicals or chemical catalysts with substantial energy consumption, and the reactions have limited specificity, resulting in the formation of byproducts, especially when using complex medias such as oily wastewaters. To turn the processes more environmentally friendly, the use of enzymes has demonstrated to be a great alternative. In the case of oily wastewaters, lipases can be used to degrade and modify the oil fraction through hydrolysis, esterification, and transesterification reactions.

Therefore, this study aims to review the main aspects related to the treatment and valorization of oily wastewater from agro-industries using lipases. The main features of oily wastewater are addressed as well as the conventional techniques most used for its treatment. Some relevant information about lipases is discussed and the use of these enzymes for the treatment and valorization of oily wastewaters, focusing on agro-industrial wastewaters, is highlighted. The objective is to show the several possibilities of biocatalysis using lipases for the transformation of oily wastewaters into less pollutant streams and/or value-added products. For this, the past 10-years of research work was accessed and reviewed from five databases (Scopus, Web of Science, Springer, Taylor and Francis, and Science Direct) using the portal of journals from Coordenação de Aperfeiçoamento de Pessoal de Nível Superior (CAPES).

\section{Oily wastewater from food industry}

Agro-industries produce a huge amount of wastewater with high lipid content originated from animal (dairy and meat industries) or vegetable sources (sunflower, soybean, corn canola, coconut, olive oil industries and else). These lipids are composed of oils, greases, fats, or longchain fatty acids that increase the complexity and costs of the wastewater treatment (BELDEAN-GALEA et al., 2013). Fats, oils and greases are predominantly composed of triacylglycerol, which are esters formed of glycerol and three fatty acids. In addition to triacylglycerol, several minor components are also present such as mono and diglycerides (important as emulsifiers), free fatty acids, tocopherol (an important antioxidant), sterols and vitamins from soluble fats (GRILO et al., 2014). Table 1 shows the fat, oil and grease contents of some industrial wastewaters. 
Besides a high content of lipids, wastewaters from agro-industrial food processing, such as edible oil industries, generally have high chemical oxygen demand (COD), biological oxygen demand (BOD), total suspended solids (TSS), total dissolved solids (TDS), phosphates and sulfates (AHMAD et al., 2020; ASLAN et al., 2009; NWEKE; NWABANNE; IGBOKWE, 2014). However, the composition and the characteristics of oily wastewater vary between different industries and also between different batches in the same industry (AHMAD et al., 2020; NWEKE; NWABANNE; IGBOKWE, 2014). Thus, a proper characterization of the wastewater is necessary to determine which treatments and/or reuse/valorization processes are more adequate and feasible. If the wastewater treatment fails in removing fats, oils and greases from the effluent, these compounds can cause severe environmental damages, as well as public health issues and agricultural production losses, as summarized in Figure 1.

Table 1. Oil and grease composition of different agro-industrial wastewaters.

\begin{tabular}{ccc}
\hline Source & Fat, oil and grease $(\mathrm{mg} / \mathrm{L})$ & Reference \\
\hline Sea food processing & $250-5,000$ & (KLAUCANS; SAMS, 2018) \\
Meat processing & $100-2,000$ & (KLAUCANS; SAMS, 2018) \\
Poultry slaughterhouse & 1,200 & (DAMASCENO et al., 2018) \\
Dairy industry & 350 & (KURUP; ADHIKARI; ZISU, 2019) \\
Vegetable oil industry & 54 & (SHARGHI; SHORGASHTI; BONAKDARPOUR, 2016) \\
Vegetable oil industry & $413-667$ & (MA et al., 2015) \\
Palm oil mill & 4,000 & (SINGH et al., 2010) \\
Palm oil mill & 3,580 & (IWUAGWU; UGWUANYI, 2014) \\
Sunflower oil industry & $533-760$ & (ASLAN et al., 2009) \\
Sunflower oil refinery & 74 & (GHASEMIAN; SHARGHI; DAVARPANAH, 2017) \\
Soya oil refinery & 1550 & (RAJKUMAR; MUTHUKUMAR; SIVAKUMAR, 2010) \\
Corn oil industry & $308-499$ & (ASLAN et al., 2009)
\end{tabular}

Source: Authors.

When discharged into the sewer system, the oil can cause great damages to the city infrastructure, such as the clogging of pipes and channels, and increase the costs of the treatment since more chemicals are needed (WALLACE et al., 2017). The clogging can result in increased pressure in the pipeline and consequent leakage of the sewage into the soil. These leakages can reach the groundwater or cause sewage reflux to the surface.

Once the oil passes through the sewer system and enters the sewage treatment plants, it can cause an overloading of the process, decreasing the treatment's efficiency. The oil can also cause blockages in the plant infrastructure. These issues increase the costs of operation and maintenance of the treatment system (WALLACE et al., 2017). It is estimated that fats, oils and greases correspond to $25 \%$ of the sewage treatment cost (EUROPEAN BIOMASS INDUSTRY ASSOCIATION, 2015). Besides, high concentrations of oil in the wastewater can negatively 
affect the performance of microorganisms in degrading it as well as other organic compounds. Thus, a slower degradation rate can lead to oil discharge with the treated effluent directly to water bodies (WALLACE et al., 2017).

Figure 1. Main effects of the incorrect disposal of oily wastewater in the sewage system, water bodies and soil.

EFFECTS OF OILY WASTEWATER INCORRECT DISPOSAL

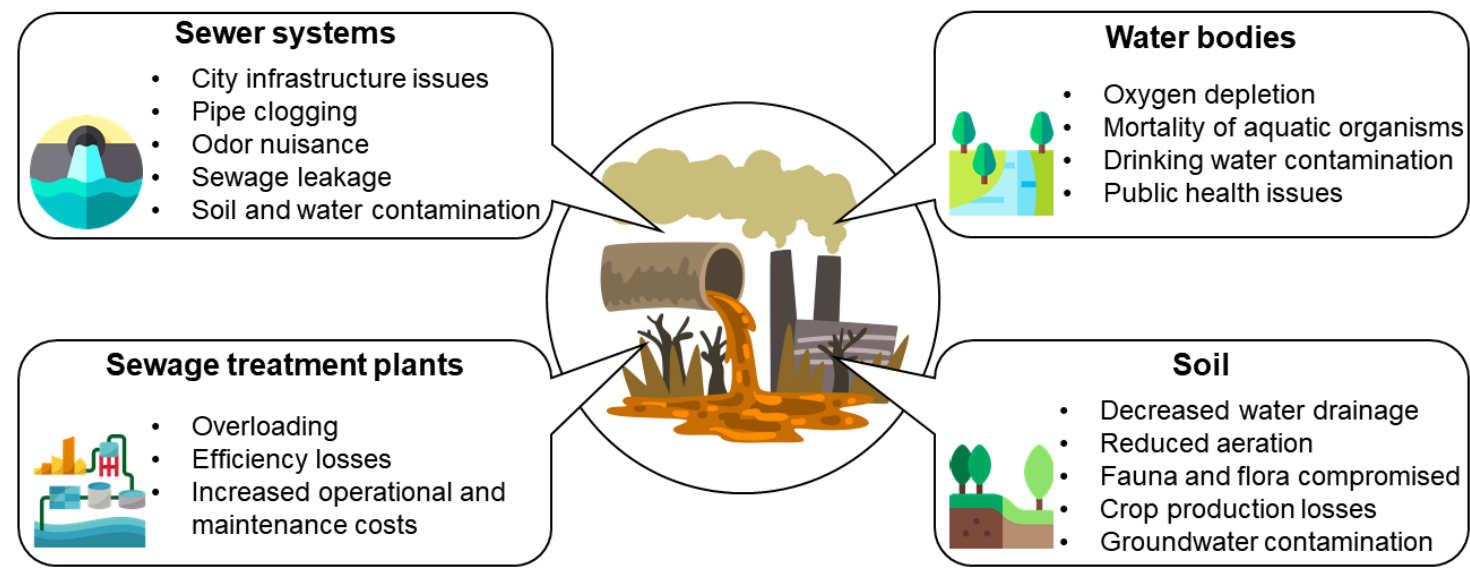

Source: Authors.

When discharged in water bodies, the oil can end up forming a thin film on the water surface, preventing the entry of sunlight and gaseous exchanges. Thus, the aeration process is compromised and, due to oxygen depletion, the aerobic organisms are affected (FINGAS, 2015). Once in the soil, the oil changes the soil's physical properties by clogging the pores, which promotes the soil waterproofing, decreasing water drainage and aeration (SANTOS; MARANHO, 2018). Thus, all fauna and flora present in the soil are compromised, which can affect crop production. Besides, depending on the physical-chemical characteristics of the soil, the relief and the climate, the oil can penetrate the soil and/or runoff, reaching the groundwater and the surface water bodies close to the discharge point (YANXUN et al., 2011).

The importance of proper management and treatment of the oily wastewaters generated in agro-industries is unquestionable not only to comply with environmental regulations and standards but also to avoid environmental and public health issues. The next topic approaches some conventional techniques used for the treatment of oily wastewaters.

\section{Conventional treatments of oily food waste}

Different conventional techniques are used for the treatment of oily wastewater, including physical (such as gravity settling and flotation), chemical (such as flocculation and coagulation), and biological processes (aerobic and anaerobic digestion) (LOUHICHI et al., 
2019). In typical wastewater treatment plants, a combination of treatments is applied, generally, a physical-chemical process followed by biological degradation. The appropriate technology is usually dictated by the characteristics of the compounds present in the wastewater. The degree of dispersion and the stability of the oil droplets are the most important factors. These characteristics are ruled by the diameter of the droplets: free oil (>150 $\mu \mathrm{m})$, dispersed oil (20$150 \mu \mathrm{m})$, emulsified oil $(<20 \mu \mathrm{m})$ and soluble oil $(<5 \mu \mathrm{m})$ (PINTOR et al., 2016).

Physical methods are mainly used for the separation of the oil fraction from the wastewater. Free, dispersed, and some emulsified oil can be removed by these methods. The most used physical techniques in agro-industrial wastewater treatment are gravity settling and flotation. In the gravity settling process, the wastewater is kept in a tank with no intervention until the oil phase rises to the surface (LONG, 1995). It is a simple, low cost and easy to maintain method. However, depending on the wastewater characteristics, large retention times are necessary to reach a good oil removal. To accelerate the process, flotation can be used. Flotation is based on the preferential adherence of the oil phase into bubbles of a gas (generally air) that permeates the suspension, being carried to the surface because of its lower density (YU; HAN; HE, 2017). The oil removal efficiency by flotation is influenced mainly by $\mathrm{pH}$, gas flow rate, bubble size, bubble rising velocity, and bubble formation frequency (PAINMANAKUL et al., 2010). Although this method generates low volumes of sludge, it presents high energy consumption for the generation of the bubbles and high maintenance costs (YU; HAN; HE, 2017). In both methods, once in the surface, the concentrated oil fraction can be mechanically skimmed off or allowed to overflow from the settler/flotation tank (LONG, 1995).

The main chemical conventional methods used in agro-industrial wastewater treatment plants are flocculation and coagulation. These methods are mostly used for the removal of free, dispersed, and mainly for coarse emulsified oil. First, the coagulation process causes the destabilization of the oil droplets, breaking the emulsion through the addition of appropriate chemicals that promote the attraction between the oil droplets (TANSEL; SEVIMOGLU, 2006). Generally, saline solutions with high ionic strength (such as aluminum and ferric salts) or polymers are used. Then, the destabilized oil droplets are induced to coalesce and flocculation occurs, forming large agglomerates that can be easily separated by flotation or gravity settling (KHOUNI et al., 2020). However, high consumption of chemicals and high sludge generation are the major drawbacks of these methods (MA et al., 2015).

Chemical methods have limitations in removing fine emulsified oil and soluble oil. Thus, in conventional treatment processes, physical-chemical methods are followed by biological methods. Biological methods consist of the use of microbial metabolisms to 
transform complex and potentially toxic pollutants into harmless substances (YU; HAN; HE, 2017). Biological processes are classified according to oxygen demand into aerobic and anaerobic treatments that can be used alone or in combination (AHMAD et al., 2020). Aerobic treatments require the presence of oxygen and can remove a great fraction of the organic content of the oily wastewaters. They can be applied at room temperature $\left(25-35^{\circ} \mathrm{C}\right)$ but require adequate aeration and $\mathrm{pH}$ adjustment for an efficient performance (GUNAY; KARADAG, 2015). Thus, high energy requirements for aeration is a disadvantage of the method, as well as possible bulking sludge and excessive biomass growth (TIMMERMANS; VAN HAUTE, 1984; VIDAL et al., 2000). Furthermore, the presence of a high concentration of oil in the wastewater can have a detrimental impact on oxygen transfer efficiency, compromising the aerobic process effectiveness, and the low activity associated with the excessive quantity of oil delays sedimentation which can cause biomass loss through the reactor's outflow (CAMMAROTA; FREIRE, 2006; CHAO; YANG, 1981).

To reduce the costs with aeration and the sludge formation, anaerobic processes can be an alternative to treat oily wastewaters. Anaerobic processes occur in the absence of oxygen (so no aeration is needed) and present high retention time and slow microbial growth when compared to aerobic processes (OHIMAIN; IZAH, 2017). Normally, the degradation of organic pollutants by anaerobic digestion consists of four steps: hydrolysis, acidogenesis, acetogenesis, and methanogenesis (AHMED et al., 2015). If the biodegradation is complete, the end products are methane and carbon dioxide. As methane is one of the end products of anaerobic digestion, anaerobic treatments can be applied in combination with biogas production, a biofuel that can be used by the industry itself (AHMED et al., 2015; KALAT; YÜCEER, 2017). In general, when compared to aerobic digestion, anaerobic systems have shown higher removal efficiencies, lower cost, and lower sludge production, besides enabling the conversion of waste to useful products (AHMAD et al., 2020; DOULA et al., 2017). However, anaerobic processes generally require longer retention times and larger surface areas due to slow startup (ALHAJI et al., 2016; STRONACH; RUDD; LESTER, 1986). The Up-flow Anaerobic Sludge Blanket (UASB) is the most popular anaerobic digestor applied for the treatment of wastewater with high organic load (GUNAY; KARADAG, 2015). UASB reactors are considered a low-cost and efficient high-rate anaerobic treatment system, which is due to the retention of high concentrations of biomass, the upward flow of the wastewater (no agitation needed), the ability to resist to low concentrations of oxygen without compromise the microbial metabolic activities, and the possibility of producing biogas (CHIPASA; MĘDRZYCKA, 2006; LETTINGA, 1995; STRONACH; RUDD; LESTER, 1986). Although UASB reactors have 
shown great performances in the treatment of high organic load wastewaters, some problems were reported when treating lipid-rich wastewater, such as flotation of the biomass granules due to fat, oil and/or grease adsorption (CHIPASA; MĘDRZYCKA, 2006; RINZEMA; ALPHENAAR; LETTINGA, 2007) and inhibitory effects of the long-chain fatty acids on the anaerobic microorganisms (KOSTER; CRAMER, 1987; LALMAN; BAGLEY, 2001; NING et al., 2018). These problems can be solved by applying a pre-treatment of the wastewater to remove free and suspended lipids and by using lipid-tolerant microorganisms (DAMASCENO et al., 2018; DEL NERY et al., 2007).

Generally, a physical-chemical method is followed by a biological method for the treatment of wastewater with high lipids load. The goal of the physical-chemical method is to remove coarse lipids that would compromise the biological process. However, the physicalchemical techniques only remove the lipid fraction and the generated sludge must be properly treated and disposed of, which represent a huge cost for the industry, in addition to often being an environmental liability. Based on this, the development of new techniques able to degrade even coarse lipids is fundamental to make the wastewater treatment cheaper and more environmentally friendly by minimizing sludge production. Moreover, the lipids that pass to the biological treatment can inhibit the metabolism of the microorganisms, increase the retention time needed to adequate biodegradation, and cause biomass flotation leading to biomass washout. Thus, a pre-treatment able to degrade the triacylglycerols to less complex molecules could decrease retention time and avoid failure of the biological process. Based on this, the treatment of oily wastewater using enzymes, mainly lipases, is an environmentally friendly alternative that can be used before or in combination with the biological treatment. Enzymes can be used to degrade the lipids and/or convert them into valuable products. The next section will elucidate the many possibilities regarding lipases and their use in the treatment and/or valorization of oily wastewaters.

\section{Lipases}

Lipases (triacylglycerol acyl hydrolases, E.C. 3.1.1.3) are enzymes that have the natural ability to act at an organic-aqueous interface catalyzing the total or partial hydrolysis of carboxylate ester bonds of triacylglycerol to diacylglycerol, monoacylglycerol, glycerol and free fatty acids in an aqueous medium (Figure 2a). The hydrolysis of triacylglycerols occurs by sequential cleavage of the acyl groups in the glyceride, in such a way that, in a given instant, the reaction mixture can contain triglycerides, diacylglycerols, monoacylglycerols, glycerol and fatty acids simultaneously. Since the equilibrium between the forward and reverse reactions is 
controlled by the water activity, i.e. water concentration in the reaction media, under waterrestrict conditions, the reverse reaction (esterification) can occur (Figure 2b) (BORRELLI; TRONO, 2015). Different transesterification reactions can also occur at low water content, such as exchange of groups between two esters (Figure 2c), between an ester and an alcohol (alcoholysis, Figure 2d), an ester and an acid (acidolysis, Figure 2e), and an ester and an amine (aminolysis, Figure 2f) (BORRELLI; TRONO, 2015).

Figure 2. Reactions catalyzed by lipases.
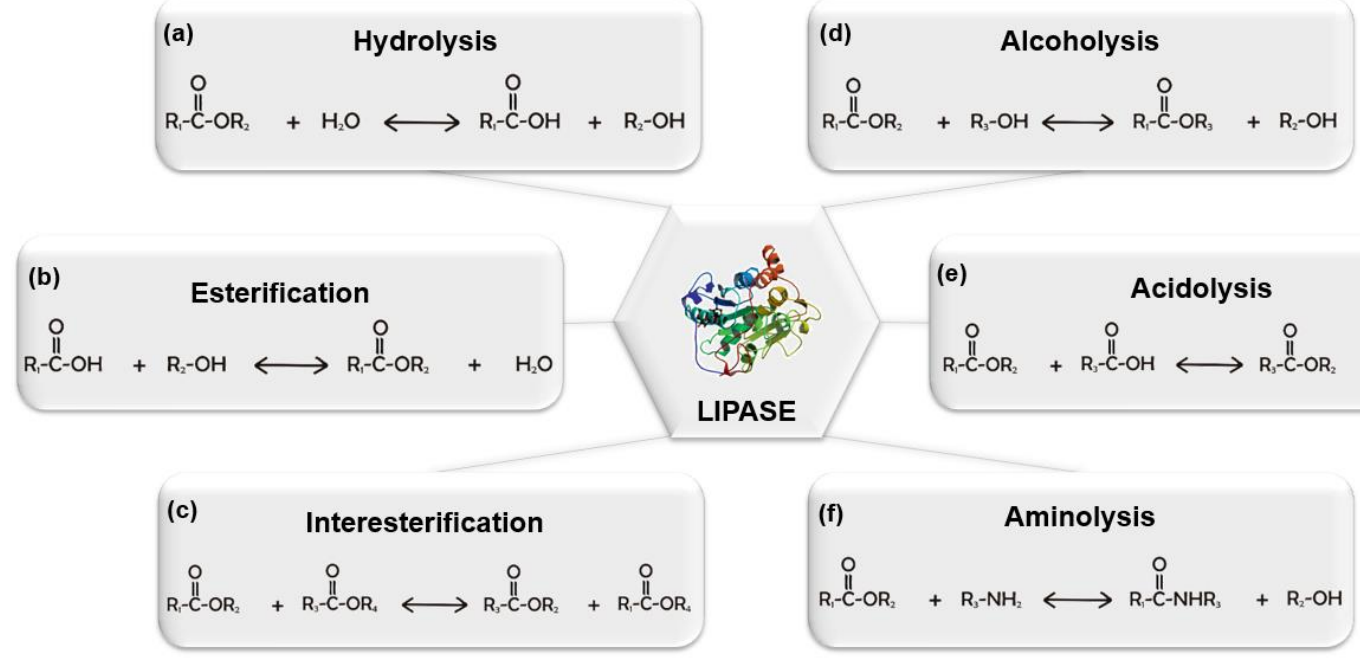

Source: Authors.

Lipases have a great affinity with a wide range of substrates, high stability to temperature, $\mathrm{pH}$, and organic solvents, and can be chemoselective, regioselective and enantioselective (BARROS; FLEURI; MACEDO, 2010; GOLUNSKI et al., 2016). Due to these features and the ability to catalyze hydrolysis and synthesis reactions, lipases have been used in several applications in the pharmaceutical, food, chemical and cosmetic industries, in the formulation of detergents and the production of biodiesel (ALMEIDA et al., 2019; BOROWIECKI; DRANKA, 2019; ĆOROVIĆ et al., 2020; JAHANGIRI et al., 2018; MURILLO et al., 2019; PHUKON et al., 2020).

Lipases can be produced from microorganisms (bacteria or fungi), plants (mainly from seeds and latex), and animals (pancreatic, hepatic or gastric lipases). Microbial lipases are the most used ones due to the easier extraction process that allows large-scale production (COSTA et al., 2017; JOSHI; SHARMA; KUILA, 2019). Fungi are the most used microorganisms to lipase production since the lipases produced by them are extracellular in nature and then can be easily extracted from the fermentation media, reducing the production costs (MEHTA; BODH; 
GUPTA, 2017). The fermentation process can be conducted in two ways, by solid-state fermentation or by submerged fermentation. Solid-state fermentation consists of a fermentation process on solid substrates in the absence or almost absence of water, while submerged fermentation takes place in a liquid medium containing soluble nutrients (CASTILHO et al., 2000). Submerged fermentation is widely used due to the easier control of operational parameters such as temperature and $\mathrm{pH}$, and for having higher homogeneity than solid-state fermentation, which makes nutrient transfer more efficient (COLLA et al., 2016). However, submerged fermentation can have limited oxygen transfer if the agitation is not adequate, which is worsened in the case of fungi due to the filamentous morphology of hyphae in liquid media (COLLA et al., 2016). Solid-state fermentation, in turn, can have lower costs due to less water and energy demand (no agitation needed). In both cases, lipase-producing fungi can be grown in synthetic media or in natural media, such as agro-industrial residues, which besides being a substrate for the growth of the microorganisms, are also a source of carbon and nitrogen (RAVINDRAN et al., 2018). The use of waste for the production of lipases as well as other bioproducts has several advantages such as the reduction of process costs, the valorization of low value-added materials, and the reduction of environmental pollution. Table 2 shows some examples of lipases produced by submerged or solid-state fermentation using different microorganisms grown in agro-industrial residues.

Table 2. Microbial lipases produced through fermentation using agro-industrial residues as substrate.

\begin{tabular}{|c|c|c|c|c|}
\hline Substrate & Microorganism & Fermentation & Lipase yield & Reference \\
\hline Cottonseed oil cake & Cryptococcus sp. & Solid-state & $753 \mathrm{U} / \mathrm{g}^{*}$ & $\begin{array}{l}\text { (THIRUNAVUKARASU et al. } \\
\text { 2016) }\end{array}$ \\
\hline Canola cake & Aspergillus niger & Solid-state & $837 \mathrm{U} / \mathrm{g}$ & (TREICHEL et al., 2016) \\
\hline Sugarcane bagasse & $\begin{array}{l}\text { Rhizomucor sp. and } \\
\text { Penicillium } \mathrm{sp} .\end{array}$ & Solid-state & $\begin{array}{c}0.58 \mathrm{U} / \mathrm{g} \text { and } \\
0.47 \mathrm{U} / \mathrm{g}\end{array}$ & (PINOTTI et al., 2017) \\
\hline Castor seed cake & $\begin{array}{l}\text { Aspergillus oryzae and } \\
\text { Aspergillus japonicas }\end{array}$ & Solid-state & $\begin{array}{l}25 \mathrm{U} / \mathrm{g} \text { and } \\
19 \mathrm{U} / \mathrm{g}\end{array}$ & (JAIN; NAIK, 2018) \\
\hline Soapstock & Candida rugosa & Submerged & $7,400 \mathrm{U} / \mathrm{L}^{* *}$ & $\begin{array}{l}\text { (ABDELMOEZ; MOSTAFA; } \\
\text { MUSTAFA, 2013) }\end{array}$ \\
\hline $\begin{array}{l}\text { Palm oil mill } \\
\text { wastewater }\end{array}$ & Bacillus niacini & Submerged & $31,000 \mathrm{U} / \mathrm{L}$ & (OYEDELE et al., 2019) \\
\hline Mango seed and peel & Yarrowia lipolytica & Submerged & $3,500 \mathrm{U} / \mathrm{L}$ & $\begin{array}{c}\text { (PEREIRA; FONTES- } \\
\text { SANT'ANA; AMARAL, 2019) }\end{array}$ \\
\hline
\end{tabular}

*Units of enzymatic activity per gram of solid substrate; ${ }^{* *}$ Units of enzymatic activity per liter of submerged media. Source: Authors.

Lipases produced by different microorganisms in diverse conditions can have distinct characteristics in terms of selectivity, activity, specificity, stability, and structure. Normally, the lipase structure is formed by an $\alpha-\beta$ hydrolase fold and a catalytic triad composed of the amino 
acids serine, histidine and aspartic acid or glutamic acid (MULINARI; OLIVEIRA; HOTZA, In press). It has four substrate-binding sites: three pockets and an oxyanion hole. The pockets hold the fatty acids of the substrate at sn-1, sn-2 and sn-3 positions. In most lipases, the active site is protected by an amphiphilic $\alpha$-helix peptide sequence lid (KAPOOR; GUPTA, 2012). When in contact with a hydrophobic surface, the hydrophobic residues of the lid are exposed, opening the lid and turning the catalytic triad accessible to the substrate, which enhances the catalytic activity of the lipase (GUPTA; BHATTACHARYA; MURTHY, 2013). This phenomenon is called interfacial activation. However, lipases from different origins and production conditions can have distinct characteristics, such as two lids (MARAITE et al., 2013; YAACOB et al., 2016) or no lid (ADLERCREUTZ, 2013; MARTINELLE; HOLMQUIST; HULT, 1995).

Lipases with different features can be produced focusing on the application of the enzyme. Regarding the use of lipases in the treatment of oily wastewater, hydrolytic lipases are the most interesting ones since they can transform the triacylglycerols in less complex molecules, facilitating the degradation by biological processes. Besides treatment, some components of the oily wastewaters can be transformed into value-added products (such as biodiesel, surfactants, and lubricants) using lipases as catalysts. In this case, lipases with higher esterification/transesterification activity are more interesting. Based on this, the next topic approaches the use of lipases for the treatment and valorization of oily wastewaters, mainly from agro-industries.

\section{Lipases in the treatment and valorization of oily wastewaters}

While some lipases can hydrolyze only specific triacylglycerols others can catalyze the hydrolysis of triacylglycerols that contain different fatty acids in their composition, which can be of great interest for the treatment of wastewaters with a high content of lipids (BARROS; FLEURI; MACEDO, 2010; MACRAE; HAMMOND, 1985). The use of lipases reduces the organic matter concentration (in terms of COD), the color and the amount of suspended solids and lipids in the wastewater, which improves the operating conditions of the biological treatment and unclogs oil films in connection pipes, increasing the lifespan of the equipment (MENDES et al., 2005). Furthermore, the specificity of the lipase allows the control of the released products, avoiding the generation of toxic subproducts. The moderate operational conditions required by lipases and the need to add no chemicals can reduce the costs related to energy consumption and equipment (MENDES et al., 2005). 
The treatment of oily wastewater using lipases aims to hydrolyze the triacylglycerols of the oil into free fatty acids and glycerol. The lipases can be used as a pretreatment before biological treatment or in combination with the biological process. In both cases, several studies showed that the use of lipases improved the performance of the biological treatment, mainly in terms of COD reduction and biogas production, in the treatment of wastewaters from the poultry industry (AFFES et al., 2017; VALLADÃO et al., 2011) and dairy industry (ADULKAR; RATHOD, 2015; MENDES; CASTRO, 2005; ROSA et al., 2009), for example. Table 3 shows some examples of studies using lipases for the hydrolysis of oily wastewaters.

Table 3. Examples of oily wastewaters treated with lipases.

\begin{tabular}{|c|c|c|c|c|}
\hline $\begin{array}{c}\text { Oily } \\
\text { wastewater }\end{array}$ & Lipase & Process conditions & Main results & Reference \\
\hline $\begin{array}{l}\text { Dairy } \\
\text { wastewater }\end{array}$ & $\begin{array}{l}\text { Porcine pancreatic } \\
\text { lipase }\end{array}$ & $\begin{array}{l}\text { Enzyme concentration of } \\
0.3 \% \quad(\mathrm{w} / \mathrm{v}) ; \quad \mathrm{pH} \quad 8 ; \\
200 \mathrm{rpm} ; 37^{\circ} \mathrm{C} ; 24 \mathrm{~h}\end{array}$ & $38 \mathrm{mM}$ of FFA & $\begin{array}{l}\text { (MENDES; } \\
\text { CASTRO, 2005) }\end{array}$ \\
\hline $\begin{array}{l}\text { Swine meat } \\
\text { industry } \\
\text { wastewater }\end{array}$ & $\begin{array}{l}\text { Penicillium } \\
\text { restrictum lipase }\end{array}$ & $\begin{array}{l}\text { Enzyme concentration of } \\
5 \%(\mathrm{w} / \mathrm{v}) ; 45^{\circ} \mathrm{C} ; 10 \mathrm{~g} / \mathrm{L} \\
\text { of oil and grease; } \mathrm{pH} 6 \text {; } \\
100 \mathrm{rpm} ; 24 \mathrm{~h}\end{array}$ & $\begin{array}{l}100 \mu \mathrm{mol} / \mathrm{mL} \text { of } \\
\text { FFA }\end{array}$ & (RIGO et al., 2008) \\
\hline $\begin{array}{l}\text { Waste } \\
\text { cooking oil } \\
\text { (WCO) }\end{array}$ & $\begin{array}{l}\text { Aspergillus niger } \\
\text { lipase }\end{array}$ & \begin{tabular}{lr} 
Ultrasound-assisted \\
hydrolysis; $\quad 45$ \\
oil:water & \multicolumn{2}{l}{${ }^{\circ} \mathrm{C}$; } \\
$1: 3(\mathrm{v}: \mathrm{v}) ;$ & enzyme \\
concentration & of \\
$15 \%(\mathrm{v} / \mathrm{v}) ;$ & $12 \mathrm{~h} ; 170 \mathrm{rpm}$
\end{tabular} & $63 \mu \mathrm{mol} / \mathrm{mL}$ of FFA & $\begin{array}{l}\text { (MULINARI et al., } \\
\text { 2017) }\end{array}$ \\
\hline $\begin{array}{l}\text { Leather } \\
\text { industry } \\
\text { wastewater }\end{array}$ & $\begin{array}{l}\text { Bacillus cereus } \\
\text { lipase immobilized } \\
\text { in nanoporous- } \\
\text { activated carbon }\end{array}$ & $\begin{array}{l}\text { Packed bed reactor; } \\
60 \text { min; } \mathrm{pH} 10 ; 40{ }^{\circ} \mathrm{C}\end{array}$ & $\begin{array}{l}99 \% \text { of fat } \\
\text { degradation }\end{array}$ & $\begin{array}{l}\text { (POUNSAMY } \\
\text { al., 2019) }\end{array}$ \\
\hline $\begin{array}{l}\text { Pet food } \\
\text { industry } \\
\text { wastewater }\end{array}$ & $\begin{array}{l}\text { Candida rugosa } \\
\text { lipase immobilized } \\
\text { in hybrid sol- } \\
\text { gel/calcium alginate } \\
\text { beads }\end{array}$ & $\begin{array}{l}\text { Enzymatic hydrolysis } \\
\text { followed by anaerobic } \\
\text { biodegradation; } 5 \%(\mathrm{v} / \mathrm{v}) \\
\text { of wastewater; } 0.04 \mathrm{~g} \\
\text { beads/g oil; } \mathrm{pH} 6.8 \text {; } \\
150 \mathrm{rpm} ; 37^{\circ} \mathrm{C} ; 30 \mathrm{~min}\end{array}$ & $\begin{array}{l}\text { Enhanced COD and } \\
\text { grease removal; } \\
\text { higher biogas } \\
\text { production; no foam } \\
\text { production }\end{array}$ & $\begin{array}{l}\text { (JEGANATHAN; } \\
\text { NAKHLA; BASSI, } \\
2007)\end{array}$ \\
\hline $\begin{array}{l}\text { Fish- } \\
\text { processing } \\
\text { plant } \\
\text { wastewater }\end{array}$ & $\begin{array}{l}\text { Penicillium } \\
\text { simplicissimum } \\
\text { lipase }\end{array}$ & $\begin{array}{l}\text { Enzymatic hydrolysis } \\
\text { followed by anaerobic } \\
\text { biodegradation; } \\
1,500 \mathrm{mg} / \mathrm{L} \text { of oil and } \\
\text { grease; } 8 \mathrm{~h} ; 30{ }^{\circ} \mathrm{C} \text {; } \\
150 \mathrm{rpm} \text {; p } 5\end{array}$ & $\begin{array}{l}\text { Enhanced COD } \\
\text { reduction from } 80 \text { to } \\
91 \%\end{array}$ & $\begin{array}{l}\text { (ALEXANDRE et } \\
\text { al., 2011) }\end{array}$ \\
\hline $\begin{array}{l}\text { Desiccated } \\
\text { coconut } \\
\text { processing } \\
\text { plant } \\
\text { wastewater }\end{array}$ & $\begin{array}{l}\text { Porcine pancreatic } \\
\text { lipase }\end{array}$ & $\begin{array}{l}\text { Enzymatic hydrolysis } \\
\text { followed by anaerobic } \\
\text { biodegradation; } 37{ }^{\circ} \mathrm{C} \text {; } \\
100 \mathrm{rpm} ; 24 \mathrm{~h} \text {; enzyme } \\
\text { concentration } \\
0.1 \%(\mathrm{v} / \mathrm{v})\end{array}$ & $\begin{array}{l}\text { Higher initial biogas } \\
\text { production rate }(25 \\
\text { mL/day) and higher } \\
\text { daily production } \\
\text { during first } 10 \text { days. }\end{array}$ & $\begin{array}{l}\text { (SAMARASIRI; } \\
\text { RATHNASIRI; } \\
\text { FERNANDO; } \\
\text { 2019) }\end{array}$ \\
\hline
\end{tabular}


However, before thinking about the treatment of oily wastewater, the reuse and valorization of its components must be taken into account. Agro-industrial waste (including oily wastewaters) contains several valuable compounds that can be recovered, reused, transformed, and utilized in a variety of applications (AHMAD et al., 2020). The biotransformation of the oily wastewaters can generate commercially important products such as biofuels, surfactants, lubricants, organic acids, glycerol, among others (AHMAD et al., 2020; ANDLER; GODDARD, 2018). Table 4 shows some examples of value-added products produced from oily wastewaters by lipase-catalyzed processes.

Table 4. Valorization of oily wastewater through lipase-catalyzed processes aiming for the production of valueadded products.

\begin{tabular}{|c|c|c|c|c|}
\hline $\begin{array}{c}\text { Oily } \\
\text { wastewater }\end{array}$ & Lipase & Catalyzed reaction & Main results & Reference \\
\hline $\begin{array}{l}\text { Waste } \\
\text { cooking oil } \\
(\text { WCO })\end{array}$ & $\begin{array}{l}\text { Candida rugosa } \\
\text { lipase } \\
\text { immobilized in } \\
\text { polyethersulphone } \\
\text { hollow fiber } \\
\text { membrane }\end{array}$ & $\begin{array}{l}\text { Submerged membrane } \\
\text { reactor; } 80 \mathrm{kPa} ; \mathrm{pH} 7 \\
35^{\circ} \mathrm{C} ; \text { aqueous phase } \\
\text { flow rate of } 0.06 \mathrm{~m} / \mathrm{s} \text {; } \\
\text { organic phase stirring of } \\
89 \mathrm{rad} / \mathrm{s} ; 27 \mathrm{~min} \text {. }\end{array}$ & $250 \mathrm{mmol} / \mathrm{L} . \mathrm{h}$ of FFA & $\begin{array}{l}\text { (CHAKRABORTY; } \\
\text { DRIOLI; GIORNO, } \\
2012 \text { ) }\end{array}$ \\
\hline $\begin{array}{l}\text { Olive mill } \\
\text { wastewater } \\
(\text { OMW) }\end{array}$ & Novozyme 435 & $\begin{array}{l}\text { Esterification of tyrosol } \\
\text { and hydroxytyrosol } \\
\text { extracted from OMW } \\
\text { with butyric, decanoic, } \\
\text { lauric, and palmitic acids; } \\
\text { OMW:fatty acid } 1: 8 \\
(\mathrm{~m} / \mathrm{m}) ; 45^{\circ} \mathrm{C} ; 200 \mathrm{rpm} ; \\
72 \mathrm{~h} .\end{array}$ & 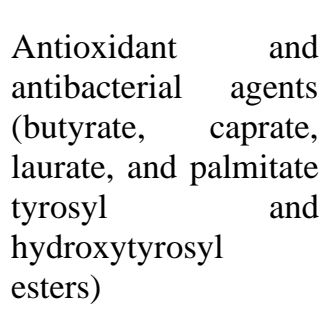 & (AISSA et al., 2017) \\
\hline $\begin{array}{l}\text { Recovered } \\
\text { coconut oil } \\
(\mathrm{RCO})\end{array}$ & $\begin{array}{l}\text { Thermomyces } \\
\text { lanuginosa lipase }\end{array}$ & $\begin{array}{l}\text { Modification of maize } \\
\text { and cassava starches by } \\
\text { enzymatic esterification } \\
\text { with RCO fatty acids. }\end{array}$ & $\begin{array}{l}\text { Thermoplastic } \\
\text { starches (which can } \\
\text { be used in plastic and } \\
\text { pharmaceutical } \\
\text { industries) }\end{array}$ & $\begin{array}{l}\text { (RAJAN; PRASAD; } \\
\text { ABRAHAM, 2006) }\end{array}$ \\
\hline $\begin{array}{l}\text { Waste } \\
\text { cooking oil } \\
(\text { WCO) }\end{array}$ & $\begin{array}{l}\text { Immobilized } \\
\text { lipases Lipozyme } \\
\text { TL IM and } \\
\text { Novozym } 435\end{array}$ & $\begin{array}{l}\text { Continuous esterification } \\
\text { in ultrasound-assisted } \\
\text { system. }\end{array}$ & $\begin{array}{l}79 \% \text { conversion of } \\
\text { WCO hydrolysates in } \\
\text { ethyl esters after } \\
9 \text { min }\end{array}$ & $\begin{array}{l}\text { (ZENEVICZ et al., } \\
2017)\end{array}$ \\
\hline $\begin{array}{l}\text { Palm oil mill } \\
\text { effluent } \\
\text { (POME) }\end{array}$ & Candida sp. lipase & $\begin{array}{l}\text { Enzymatic hydrolysis (40 } \\
{ }^{\circ} \mathrm{C}, \mathrm{pH} 7,650 \mathrm{rpm}, 20 \\
\mathrm{U} / \mathrm{mL} \text { of enzyme, } 50 \% \\
(\mathrm{v} / \mathrm{v}) \text { of } \mathrm{POME}) \text { followed } \\
\text { by non-catalytic } \\
\text { esterification }\left(75^{\circ} \mathrm{C}, 950\right. \\
\text { rpm, alcohol to fatty acid } \\
\text { ratio of } 3: 1) .\end{array}$ & $\begin{array}{l}\text { Bio-lubricant; } \\
\text { hydrolysis rate of } 0.16 \\
\text { mg/s.L; esterification } \\
\text { rate of } 0.0018 \mathrm{mg} / \mathrm{s} . \mathrm{L}\end{array}$ & $\begin{array}{l}\text { (SYAIMA et al., } \\
2015)\end{array}$ \\
\hline $\begin{array}{l}\text { Waste frying } \\
\text { palm oil }\end{array}$ & $\begin{array}{l}\text { Candida } \\
\text { antarctica lipase }\end{array}$ & $\begin{array}{l}16.6 \% \quad(\mathrm{w} / \mathrm{w}) \\
\text { content; } 5.5 \% \quad(\mathrm{w} / \mathrm{w}) \\
\text { lipase load; } 30{ }^{\circ} \mathrm{C} ; 22 \mathrm{~h} .\end{array}$ & $\begin{array}{l}\text { Biodiesel yield of } \\
95 \%\end{array}$ & $\begin{array}{l}\text { (GUO; SUN; LIU, } \\
2020)\end{array}$ \\
\hline
\end{tabular}


The enzymatic production of biodiesel from oily wastewater using lipases is the most broadly studied, since the use of commercial vegetable oils makes biodiesel more expensive than conventional diesel (ALPTEKIN; CANAKCI; SANLI, 2014). The use of edible oils for biodiesel production can also cause an increase in vegetable oil prices and represent a competition with food production, inflating the debate food versus energy since more crops would be needed specifically for biofuel (ALPTEKIN; CANAKCI; SANLI, 2014; ZHANG et al., 2010). For biodiesel production, lipases catalyze esterification and transesterification reactions to produce specific esters from fatty acids. The use of lipases prevents soap formation during transesterification, reducing the generation of byproducts and avoiding operational problems (ANDLER; GODDARD, 2018). Furthermore, lipases require more moderate processing conditions than chemical catalysts and can act in solvent-free mediums, improving the process sustainability (ANDLER; GODDARD, 2018)

However, the high cost of commercial lipases is a limiting factor for the use of the enzyme in wastewater treatment, which demonstrates the importance of developing lipase production techniques through highly efficient microorganisms using low-cost substrates as agro-industrial residues. Besides, for the use of enzymes to become competitive, their reuse is necessary and, although good conversions are reported in the literature, the vast majority of the studies use the enzyme in its free form (NIELSEN; BRASK; FJERBAEK, 2008). Therefore, when thinking about reuse and retention of enzyme activity, the immobilization technique appears like an excellent alternative. In addition to facilitating the reuse of the enzyme, immobilization on solid supports can improve catalytic, thermal, and chemical stability, enable continuous operations, and significantly reduce operating costs (RAMANI et al., 2010). However, there are few commercially available immobilized lipases, such as Novozym 435 (immobilized on acrylic resin) and Lipozyme TL IM (immobilized on silica gel carriers), but the small size of the support is still a challenge for the industry in terms of the enzyme recovery at the end of the process.

The cost of the immobilized lipases, mainly the support material costs, is the main limitation for lipase use in environmental applications such as wastewater treatment and valorization (MOHAMAD et al., 2015). Thus, a rational design focused on the application of the enzyme is essential to develop a robust biocatalyst that can be successfully used at the industrial scale. This design must carefully choose the best lipase source, enzyme production conditions, support material, and immobilization procedure to obtain a highly active lipase with great stability over the aimed application. Furthermore, the biocatalysts must increase the 
environmental sustainability of the industrial processes and, at the same time, they must be economically viable so that they can compete on an equal footing with conventional processes.

\section{Final Considerations}

The use of lipases for the treatment and valorization of oily wastewaters from agroindustries has proven to be a great alternative to improve the environmental sustainability of food production. The use of lipases can enhance the quality of the treated wastewater, minimize operational issues such as pipe clogging and foam formation, and facilitate some already established procedures such as biological treatments. Though, before thinking about the treatment of the oily wastewaters, their valorization should be considered since this lipid-rich waste can be used as a renewable resource for the production of several value-added products. In this case, lipases can catalyze several important synthesis reactions, such as hydrolysis, esterification, and transesterification. However, there are still some limitations to the broader use of lipases in environmental processes, such as the reusability of the biocatalysts and the economic feasibility, which demonstrates that more studies should be performed to turn the enzymatic processes more attractive to the industries. Based on this, the use of lipases for the treatment and valorization of oily wastewater is a very active research topic, with several possibilities to be explored and improved aiming its application at the industrial level.

\section{References}

ABDELMOEZ, W.; MOSTAFA, N. A.; MUSTAFA, A. Utilization of oleochemical industry residues as substrates for lipase production for enzymatic sunflower oil hydrolysis. Journal of Cleaner Production, v. 59, p. 290-297, 15 nov. 2013.

ADLERCREUTZ, P. Immobilisation and application of lipases in organic media. Chemical Society Reviews, v. 42, n. 15, p. 6406-6436, 2013.

ADULKAR, T. V.; RATHOD, V. K. Pre-treatment of high fat content dairy wastewater using different commercial lipases. Desalination and Water Treatment, v. 53, n. 9, p. 2450-2455, 2013.

AFFES, M. et al. Effect of bacterial lipase on anaerobic co-digestion of slaughterhouse wastewater and grease in batch condition and continuous fixed-bed reactor. Lipids in Health and Disease, v. 16, n. 195, 2017.

AHMAD, T. et al. Utilization of wastewater from edible oil industry, turning waste into valuable products: a review. Trends in Food Science \& Technology, v. 99, p. 21-33, 2020.

AHMED, Y. et al. Production of biogas and performance evaluation of existing treatment processes in palm oil mill effluent (POME). Renewable and Sustainable Energy Reviews, v. 42, p. 1260-1278, 2015. 
AISSA, I. et al. Valorization of antioxidants extracted from olive mill wastewater. Biotechnology and Applied Biochemistry, v. 64, n. 4, p. 579-589, 2017.

ALEXANDRE, V. M. F. et al. Performance of anaerobic bioreactor treating fish-processing plant wastewater pre-hydrolyzed with a solid enzyme pool. Renewable Energy, v. 36, n. 12, p. 3439-3444, 2011.

ALHAJI, M. H. et al. Photocatalytic treatment technology for palm oil mill effluent (POME): a review. Process Safety and Environmental Protection, v. 102, p. 673-686, 2016.

ALMEIDA, J. M. et al. Biochemical characterization and application of a new lipase and its cognate foldase obtained from a metagenomic library derived from fat-contaminated soil. International Journal of Biological Macromolecules, v. 137, p. 442-454, 2019.

ALPTEKIN, E.; CANAKCI, M.; SANLI, H. Biodiesel production from vegetable oil and waste animal fats in a pilot plant. Waste Management, v. 34, n. 11, p. 2146-2154, 2014.

ANDLER, S. M.; GODDARD, J. M. Transforming food waste: how immobilized enzymes can valorize waste streams into revenue streams. npj Science of Food, v. 2, n. 19, 2018.

ASLAN, S. et al. Characterization and biological treatability of edible oil wastewaters. Polish Journal of Environmental Studies, v. 18, p. 533-538, 2009.

BARROS, M.; FLEURI, L. F.; MACEDO, G. A. Seed lipases: sources, applications and properties: a review. Brazilian Journal of Chemical Engineering, v. 27, p. 15-29, 2010.

BELDEAN-GALEA, M. S. et al. Characterization of the fate of lipids in wastewater treatment using a comprehensive GC $\times$ GC/qMS and statistical approach. Analytical Methods, v. 5, n. 9, p. 2315-2323, 2013.

BOROWIECKI, P.; DRANKA, M. A facile lipase-catalyzed KR approach toward enantiomerically enriched homopropargyl alcohols. Bioorganic Chemistry, v. 93, p. 102754, 2019.

BORRELLI, G. M.; TRONO, D. Recombinant lipases and phospholipases and their use as biocatalysts for industrial applications. International Journal of Molecular Sciences, v. 16, n. 9, p. 20774-20840, 2015.

CAMMAROTA, M. C.; FREIRE, D. M. G. A review on hydrolytic enzymes in the treatment of wastewater with high oil and grease content. Bioresource Technology, v. 97, n. 17, p. 2195-2210, 2006.

CASTILHO, L. R. et al. Economic analysis of lipase production by Penicillium restrictum in solid-state and submerged fermentations. Biochemical Engineering Journal, v. 4, n. 3, p. 239-247, 2000.

CHAKRABORTY, S.; DRIOLI, E.; GIORNO, L. Development of a two separate phase submerged biocatalytic membrane reactor for the production of fatty acids and glycerol from residual vegetable oil streams. Biomass and Bioenergy, v. 46, p. 574-583, 2012.

CHAO, A. C.; YANG, W. Biological treatment of wool scouring wastewater. Journal (Water Pollution Control Federation), v. 53, p. 311-317, 1981. 
CHIPASA, K. B.; MĘDRZYCKA, K. Behavior of lipids in biological wastewater treatment processes. Journal of Industrial Microbiology and Biotechnology, v. 33, n. 8, p. 635-645, 2006.

COLLA, L. M. et al. Surface response methodology for the optimization of lipase production under submerged fermentation by filamentous fungi. Brazilian Journal of Microbiology, v. 47, n. 2, p. 461-467, 2016.

ĆOROVIĆ, M. et al. Enzymatically derived oil-based L-ascorbyl esters: synthesis, antioxidant properties and controlled release from cosmetic formulations. Sustainable Chemistry and Pharmacy, v. 15, p. 100231, 2020.

COSTA, T. M. et al. Lipase production by Aspergillus niger grown in different agroindustrial wastes by solid-state fermentation. Brazilian Journal of Chemical Engineering, v. 34, n. 2, p. 419-427, 2017.

DAMASCENO, F. R. C. et al. Treatment of wastewater with high fat content employing an enzyme pool and biosurfactant: technical and economic feasibility. Brazilian Journal of Chemical Engineering, v. 35, n. 2, p. 531-542, 2018.

DEL NERY, V. et al. Long-term operating performance of a poultry slaughterhouse wastewater treatment plant. Resources, Conservation and Recycling, v. 50, p. 102-114, 2007.

DOULA, M. K. et al. Olive mill waste: recent advances for the sustainable development of olive oil industry. In: Olive Mill Waste. Elsevier, 2017. p. 29-56.

EUROPEAN BIOMASS INDUSTRY ASSOCIATION. Transformation of used cooking oil into biodiesel: from waste to resource, 2015. Available at <https://www.eubren.com/UCO_to_Biodiesel_2030_01.pdf>. Accessed in Jun. 15, 2020.

FINGAS, M. Vegetable oil spills: oil properties and behavior. In: FINGAS, M. (Ed.).

Handbook of oil spill science and technology. Hoboken, NJ: John Wiley \& Sons, Inc, 2015. p. 79-91.

GHASEMIAN, P.; SHARGHI, E. A.; DAVARPANAH, L. The influence of short values of hydraulic and sludge retention time on performance of a membrane bioreactor treating sunflower oil refinery wastewater. International Journal of Engineering, v. 30, n. 10, 2017.

GOLUNSKI, S. M. et al. Interference of salts used on aqueous two-phase systems on the quantification of total proteins. International Journal of Biological Macromolecules, v. 83, p. 30-33, 2016.

GRILO, E. C. et al. Alpha-tocopherol and gamma-tocopherol concentration in vegetable oils. Food Science and Technology, v. 34, n. 2, p. 379-385, 2014.

GUNAY, A.; KARADAG, D. Recent developments in the anaerobic digestion of olive mill effluents. Process Biochemistry, v. 50, n. 11, p. 1893-1903, 2015.

GUO, J.; SUN, S.; LIU, J. Conversion of waste frying palm oil into biodiesel using free lipase A from Candida antarctica as a novel catalyst. Fuel, v. 267, p. 117323, 2020. 
GUPTA, S.; BHATTACHARYA, A.; MURTHY, C. N. Tune to immobilize lipases on polymer membranes: techniques, factors and prospects. Biocatalysis and Agricultural Biotechnology, v. 2, n. 3, p. 171-190, 2013.

IWUAGWU, J. O.; UGWUANYI, J. O. Treatment and valorization of palm oil mill effluent through production of food grade yeast biomass. Journal of Waste Management, v. 2014, 2014.

JAHANGIRI, A. et al. Hydrophilization of bixin by lipase-catalyzed transesterification with sorbitol. Food Chemistry, v. 268, p. 203-209, 2018.

JAIN, R.; NAIK, S. N. Adding value to the oil cake as a waste from oil processing industry: production of lipase in solid state fermentation. Biocatalysis and Agricultural Biotechnology, v. 15, p. 181-184, 2018.

JEGANATHAN, J.; NAKHLA, G.; BASSI, A. Hydrolytic pretreatment of oily wastewater by immobilized lipase. Journal of Hazardous Materials, v. 145, n. 1, p. 127-135, 2007.

JOSHI, R.; SHARMA, R.; KUILA, A. Lipase production from Fusarium incarnatum KU377454 and its immobilization using $\mathrm{Fe}_{3} \mathrm{O}_{4}$ NPs for application in waste cooking oil degradation. Bioresource Technology Reports, v. 5, p. 134-140, 2019.

KALAT, D. G.; YÜCEER, A. Anaerobic mesophilic and thermophilic treatability of vegetable oil refining wastewater. Process Safety and Environmental Protection, v. 109, p. $151-157,2017$.

KAPOOR, M.; GUPTA, M. N. Lipase promiscuity and its biochemical applications. Process Biochemistry, v. 47, n. 4, p. 555-569, 2012.

KHOUNI, I. et al. Efficiency of a coagulation/flocculation-membrane filtration hybrid process for the treatment of vegetable oil refinery wastewater for safe reuse and recovery. Process Safety and Environmental Protection, v. 135, p. 323-341, 2020.

KLAUCANS, E.; SAMS, K. Problems with fat, oil, and grease (fog) in food industry wastewaters and recovered FOG recycling methods using anaerobic co-digestion: a short review. Key Engineering Materials, v. 762, p. 61-68, 2018.

KOSTER, I. W.; CRAMER, A. Inhibition of methanogenesis from acetate in granular sludge by long-chain fatty acids. Applied and Environmental Microbiology, v. 53, n. 2, p. 403409, 1987.

KURUP, G. G.; ADHIKARI, B.; ZISU, B. Recovery of proteins and lipids from dairy wastewater using food grade sodium lignosulphonate. Water Resources and Industry, v. 22, p. $100114,2019$.

LALMAN, J. A.; BAGLEY, D. M. Anaerobic degradation and methanogenic inhibitory effects of oleic and stearic acids. Water Research, v. 35, n. 12, p. 2975-2983, 2001.

LETTINGA, G. Anaerobic digestion and wastewater treatment systems. Antonie van Leeuwenhoek, v. 67, n. 1, p. 3-28, 1995. 
LONG, R. B. Separation Processes in Waste Minimization. New York: Marcel Dekker, Inc., 1995.

LOUHICHI, G. et al. Process optimization via response surface methodology in the physicochemical treatment of vegetable oil refinery wastewater. Environmental Science and Pollution Research, v. 26, n. 19, p. 18993-19011, 2019.

MA, Z. et al. Submerged membrane bioreactor for vegetable oil wastewater treatment. Chemical Engineering \& Technology, v. 38, n. 1, p. 101-109, 2015.

MACRAE, A. R.; HAMMOND, R. C. Present and future applications of lipases. Biotechnology and Genetic Engineering Reviews, v. 3, n. 1, p. 193-218, 1985.

MARAITE, A. et al. Lipase from Pseudomonas stutzeri: purification, homology modelling and rational explanation of the substrate binding mode. Journal of Molecular Catalysis B: Enzymatic, v. 87, p. 88-98, 2013.

MARTINELLE, M.; HOLMQUIST, M.; HULT, K. On the interfacial activation of Candida antarctica lipase A and B as compared with Humicola lanuginosa lipase. Biochimica et Biophysica Acta (BBA) - Lipids and Lipid Metabolism, v. 1258, n. 3, p. 272-276, 1995.

MEHTA, A.; BODH, U.; GUPTA, R. Fungal lipases: a review. Journal of Biotech Research, v. 8, p. 58-77, 2017.

MENDES, A. A. et al. Aplicação de lipases no tratamento de águas residuárias com elevados teores de lipídeos. Química Nova, v. 28, n. 2, p. 296-305, 2005.

MENDES, A. A.; CASTRO, H. F. DE. Effect on the enzymatic hydrolysis of lipids from dairy wastewater by replacing Gum Arabic emulsifier for sodium chloride. Brazilian Archives of Biology and Technology, v. 48, p. 135-142, 2005.

MOHAMAD, N. R. et al. An overview of technologies for immobilization of enzymes and surface analysis techniques for immobilized enzymes. Biotechnology \& Biotechnological Equipment, v. 29, n. 2, p. 205-220, 2015.

MULINARI, J. et al. Ultrasound-assisted hydrolysis of waste cooking oil catalyzed by homemade lipases. Ultrasonics Sonochemistry, v. 35, p. 313-318, 2017.

MULINARI, J.; OLIVEIRA, J. V.; HOTZA, D. Lipase immobilization on ceramic supports: an overview on techniques and materials. Biotechnology Advances, p. 107581, In press.

MURILLO, G. et al. Scaled-up biodiesel synthesis from Chinese Tallow Kernel oil catalyzed by Burkholderia cepacia lipase through ultrasonic assisted technology: a non-edible and alternative source of bio energy. Ultrasonics Sonochemistry, v. 58, p. 104658, 2019.

NIELSEN, P. M.; BRASK, J.; FJERBAEK, L. Enzymatic biodiesel production: technical and economical considerations. European Journal of Lipid Science and Technology, v. 110, n. 8, p. 692-700, 2008.

NING, Z. et al. Anaerobic digestion of lipid-rich swine slaughterhouse waste: methane production performance, long-chain fatty acids profile and predominant microorganisms. Bioresource Technology, v. 269, p. 426-433, 2018. 
NWEKE, C. N.; NWABANNE, J. T.; IGBOKWE, P. K. Kinetics of batch anaerobic digestion of vegetable oil wastewater. Open Journal of Water Pollution and Treatment, v. 1-10, 2014.

OHIMAIN, E. I.; IZAH, S. C. A review of biogas production from palm oil mill effluents using different configurations of bioreactors. Renewable and Sustainable Energy Reviews, v. 70, p. 242-253, 2017.

OYEDELE, S. A. et al. Enhanced lipolytic activity potential of mutant Bacillus niacini EMB5 grown on palm oil mill effluent (POME) and biochemical characterization of purified lipase. Biocatalysis and Agricultural Biotechnology, v. 18, p. 101017, 2019.

PAINMANAKUL, P. et al. Effect of bubble hydrodynamic and chemical dosage on treatment of oily wastewater by Induced Air Flotation (IAF) process. Chemical Engineering Research and Design, v. 88, n. 5, p. 693-702, 2010.

PEREIRA, A. S.; FONTES-SANT'ANA, G. C.; AMARAL, P. F. F. Mango agro-industrial wastes for lipase production from Yarrowia lipolytica and the potential of the fermented solid as a biocatalyst. Food and Bioproducts Processing, v. 115, p. 68-77, 2019.

PHUKON, L. C. et al. Production and characterisation of lipase for application in detergent industry from a novel Pseudomonas helmanticensis HS6. Bioresource Technology, v. 309, p. $123352,2020$.

PINOTTI, L. M. et al. Production of lipolytic enzymes using agro-industrial residues. Chemical Engineering Transactions, v. 56, p. 1897-1902, 2017.

PINTOR, A. M. A. et al. Oil and grease removal from wastewaters: sorption treatment as an alternative to state-of-the-art technologies: a critical review. Chemical Engineering Journal, v. 297, p. 229-255, 2016.

POUNSAMY, M. et al. Removal of fat components in high TDS leather wastewater by saline-tolerant lipase-assisted nanoporous-activated carbon. Applied biochemistry and biotechnology, v. 187, n. 2, p. 474-492, 2019.

RAJAN, A.; PRASAD, V. S.; ABRAHAM, T. E. Enzymatic esterification of starch using recovered coconut oil. International Journal of Biological Macromolecules, v. 39, n. 4, p. $265-272,2006$.

RAJKUMAR, K.; MUTHUKUMAR, M.; SIVAKUMAR, R. Novel approach for the treatment and recycle of wastewater from soya edible oil refinery industry: an economic perspective. Resources, Conservation and Recycling, v. 54, n. 10, p. 752-758, 2010.

RAMANI, K. et al. Immobilisation of Pseudomonas gessardii acidic lipase derived from beef tallow onto mesoporous activated carbon and its application on hydrolysis of olive oil.

Process Biochemistry, v. 45, n. 6, p. 986-992, 2010.

RAVINDRAN, R. et al. A review on bioconversion of agro-industrial wastes to industrially important enzymes. Bioengineering, v. 5, n. 4, p. 93, 2018. 
RIGO, E. et al. Comparison of two lipases in the hydrolysis of oil and grease in wastewater of the swine meat industry. Industrial \& Engineering Chemistry Research, v. 47, n. 6, p. 1760-1765, 2008.

RINZEMA, A.; ALPHENAAR, A.; LETTINGA, G. The effect of lauric acid shock loads on the biological and physical performance of granular sludge in UASB reactors digesting acetate. Journal of Chemical Technology \& Biotechnology, v. 46, n. 4, p. 257-266, 2007.

ROSA, D. R. et al. Performance and molecular evaluation of an anaerobic system with suspended biomass for treating wastewater with high fat content after enzymatic hydrolysis. Bioresource Technology, v. 100, n. 24, p. 6170-6176, 2009.

SAMARASIRI, B. K. T.; RATHNASIRI, P. G.; FERNANDO, D. Development of an enzymatic hydrolysis pretreatment strategy to improve batch anaerobic digestion of wastewater generated in desiccated coconut processing plants. In: Moratuwa Engineering Research Conference (MERCon), 2019, Moratuwa, Sri Lanka. Anais..., p. 314-129, 2019.

SANTOS, J. J.; MARANHO, L. T. Rhizospheric microorganisms as a solution for the recovery of soils contaminated by petroleum: a review. Journal of Environmental Management, v. 210, p. 104-113, 2018.

SINGH, R. P. et al. Composting of waste from palm oil mill: a sustainable waste management practice. Reviews in Environmental Science and Bio/Technology, v. 9, n. 4, p. 331-344, 2010.

STRONACH, S. M.; RUDD, T.; LESTER, J. N. Anaerobic digestion processes in industrial wastewater treatment. Berlin, Heidelberg: Springer Berlin Heidelberg, 1986.

SYAIMA, M. T. S. et al. The synthesis of bio-lubricant based oil by hydrolysis and noncatalytic of palm oil mill effluent (POME) using lipase. Renewable and Sustainable Energy Reviews, v. 44, p. 669-675, 2015.

TANSEL, B.; SEVIMOGLU, O. Coalescence and size distribution characteristics of oil droplets attached on flocs after coagulation. Water, Air, and Soil Pollution, v. 169, n. 1, p. 293-302, 2006.

THIRUNAVUKARASU, K. et al. Degradation of poly(butylene succinate) and poly(butylene succinate-co-butylene adipate) by a lipase from yeast Cryptococcus sp. grown on agroindustrial residues. International Biodeterioration \& Biodegradation, v. 110, p. 99-107, 2016.

TIMMERMANS, P.; VAN HAUTE, A. Influence of the type of organisms on the biomass hold-up in a fluidized-bed reactor. Applied Microbiology and Biotechnology, v. 19, n. 1, p. 36-43, 1984.

TREICHEL, H. et al. Lipase production from a newly isolated Aspergillus niger by solid state fermentation using canola cake as substrate. Current Biotechnology, v. 5, n. 4, p. 295-300, 2016.

VALLADÃO, A. B. G. et al. Profiles of fatty acids and triacylglycerols and their influence on the anaerobic biodegradability of effluents from poultry slaughterhouse. Bioresource Technology, v. 102, n. 14, p. 7043-7050, 2011. 
VIDAL, G. et al. Influence of the content in fats and proteins on the anaerobic biodegradability of dairy wastewaters. Bioresource Technology, v. 74, n. 3, p. 231-239, 2000 .

WALLACE, T. et al. International evolution of fat, oil and grease (FOG) waste management: a review. Journal of Environmental Management, v. 187, p. 424-435, 2017.

YAACOB, N. et al. Toluene promotes lid 2 interfacial activation of cold active solvent tolerant lipase from Pseudomonas fluorescens strain AMS8. Journal of Molecular Graphics and Modelling, v. 68, p. 224-235, 2016.

YANXUN, S. et al. Analysis of the groundwater and soil pollution by oil leakage. Procedia Environmental Sciences, v. 11, p. 939-944, 2011.

YU, L.; HAN, M.; HE, F. A review of treating oily wastewater. Arabian Journal of Chemistry, v. 10, p. S1913-S1922, 2017.

ZENEVICZ, M. C. P. et al. A two-step enzymatic strategy to produce ethyl esters using frying oil as substrate. Industrial Crops and Products, v. 108, p. 52-55, 2017.

ZHANG, Z. et al. Food versus fuel: what do prices tell us? Energy Policy, v. 38, n. 1, p. 445$451,2010$. 